\title{
HASIL TANGKAPAN DAN LAJU TANGKAP TUGUK (TRAP NET) DI PERAIRAN MUARA SUNGAI BARITO PROVINSI KALIMANTAN SELATAN
}

\section{Catches And Catching Rates Tuguk (Trap Net) In The Waters Of The Barito Estuaries Of South Kalimantan Province}

\author{
Makri $^{1}$, Rangga Bayu Kusuma Haris ${ }^{2}$, Rahma Mulyani ${ }^{3}$ \\ 1) Balai Riset Perikanan Perairan Umum dan Penyuluh Perikanan Palembang \\ 2) Politeknik Kelautan dan Perikanan Dumai \\ 3) Fakultas Perikanan dan Kelautan UPGRI Palembang \\ *Corresponding author: makri.brppupp@gmail.com
}

\begin{abstract}
ABSTRAK
Alat tangkap tuguk ialah salah satu jenis alat tangkap yang ditujukan untuk menangkap udang. Permasalahan pada perikanan tuguk adalah rendahnya selektivitas alat tangkap ini terhadap hasil tangkapan. Kondisi ini mengakibatkan hasil tangkapan didominasi ukuran kecil. Penelitian bertujuan untuk mengetahui hasil tangkapan dan laju tangkap tuguk. Penelitian dilakukan dengan metode observasi lapangan melalui wawancara dan pengamatan langsung terhadap hasil tangkapan tuguk yang beroperasi di muara sungai Barito. Pengamatan lapangan dilakukan bulan Maret, Mei, Agustus dan Oktober serta data enumerator bulan Maret sampai Oktober 2018. Kegiatan penangkapan menggunakan alat tangkap tuguk berdemensi ukuran bukaan mulut jaring $6 \times 7$ meter, panjang 13 meter, meshsize 1.0nbhedDDR Fi; 0.75 dan 0.25 inci sebagai kantong hasil. Hasil penelitian menunjukan kisaran laju tangkap tuguk $26.4-48.6 \mathrm{~kg} / \mathrm{hari}$, rata-rata $36.97 \mathrm{~kg} / \mathrm{hari}$. Hasil tangkapan udang memiliki laju tangkap lebih tinggi dibanding laju tangkap ikan. Rata-rata laju tangkap udang $23.28 \mathrm{~kg} / \mathrm{hari}$ atau $63 \%$, laju tangkap ikan $12.94 \mathrm{~kg} / \mathrm{hari}$ atau $35 \%$, dan laju tangkap sampingan yang dibuang (buntal, ular, anak kepiting laut dan teripang) $0.92 \mathrm{~kg}$ atau $2.48 \%$. Proporsi biomas hasil tangkapan kelompok udang didominasi udang bajang (Metapenaeus lysianassa) $25.9 \%$, kelompok ikan didominasi ikan panting famili (Ariidae sp.) $7.10 \%$ dan ikan gulama (Sciaenidae sp.) $7.53 \%$.
\end{abstract}

Kata Kunci: Tuguk, laju tangkap, trapnet, muara sungai, Barito.

\section{ABSTRACT}

Tuguk (trap net) is one of fishing gear to catch shrimp. The problem on tuguk fishing gear is low selectivity on catch product. This condition has caused the catching product dominated by small fishes. The objective of this research is to know the kind of fishing product and fishing rate of tuguk. The research used field observation method through interview and direct observe on March, May, August and October, data collection from enumerator at March - October 2018. Fishing activity used tuguk is about $6 \times 7$ meter open the net mouth 13 meters long, 1.0; 0.75; and 0.25 inch net mesh size as bag. The research shown the fishing rate of tuguk is $26.4-48.6 \mathrm{~kg} /$ day, $36.97 \mathrm{~kg} /$ day for average. The shrimp production have highest fishing rate than fish fishing rate. The fishing rate of shrimp is $23.28 \mathrm{~kg} /$ day or $63 \%$, and fishing rate for fish is $12.94 \mathrm{~kg} /$ dayor $35 \%$, and fishing rate of baycatch product (buntal, snake, baby crab, and cucumber sea) are $0.92 \mathrm{~kg} /$ day or $2.48 \%$. Biomass proportion of shrimp have dominated by Bajang shirmp (Metapeaneus lysiana) with 25.9\%, the fish dominatedeby panting fish family (Aridae, sp) with $7.10 \%$ and gulama fish (Scianidae sp) with $7.53 \%$.

Keywords: tuguk, catch rate, trapnet, estuaries, Barito 


\section{PENDAHULUAN}

Sungai Barito $(900 \mathrm{~km})$ salah satu sungai besar di Indonesia, merupakan induk sungai di Kalimantan Selatan dan Kalimantan Tengah, berawal dari lereng penggunungan Muller Kalimantan Utara, bermuara ke laut Jawa yang lebih dikenal dengan sebutan muara Banjar atau kuala Banjar (Rupawan, 2013). Perairan muara sungai salah satu ekosistem perairan pesisir yang produktif disamping ekosistem rawa pasang surut dengan hutan bakaunya, padang lamun dan terumbu karang (Supriharyono. 2007). Karakteristik lingkungan dan komunitas biota khas, komplek dan dinamis karena sangat terkait dengan pola distribusi salinitas, kekuatan arus, amplitudo pasang-surut, kekuatan ombak, pengendapan sedimen, suhu, oksigen serta penyediaan unsur hara (Suyasa et al., 2008).

Peran penting ekologis antara lain sumber zat hara dari bahan organik yang diangkut oleh sirkulasi pasang surut, tempat pemijahan, asuhan dan tempat mencari makan. Peran penting ekonomi sebagai lahan usaha perikanan tangkap, sumber pendapatan dan sumber protein hewani.

Di perairan ini penggunaan alat tangkap jaring tuguk salah satu jenis alat tangkap dominan selain alat tangkap lampara dasar dan pacing rawai. Kegiatan penangkapan dengan jaring tuguk di perairan ini sudah berlangsung lama dan turun temurun tanpa upaya pengendalian yang memadai sehingga mengarah pada hasil tangkapan yang semakin berkurang. Jaring tuguk adalah alat tangkap berbentuk jaring kantong yang dioperasikan secara pasif (pasang dan menunggu), menyaring ikan dan udang yang hanyut atau berenang bersama arus air pasang atau arus air surut. Ikan dan udang yang tertangkap dominasi ukuran individu kecil karena tidak mampu berenang melawan derasnya arus air sehingga terdesak dan terkumpul dalam kanotong hasil. (Rupawan et al., 2009).

Hasil tangkapan jaring tuguk dapat dikelompokan kedalam hasil tangkapan utama yaitu udang sebagai spesies sasaran dan hasil tangkapan sampingan. Hasil tangkapan sampinganya adalah jenis-jenis ikan demersal dan non ikan; cumi, sotong, kerang-kerangan, ubur-ubur, bintang laut. Selanjutnya hasil tangkapan sampingan jaring tuguk di kelompokan menjadi dua yaitu hasil tangkapan sampingan yang dimanfaatkan karena memiliki nilai ekonomis, diolah menjadi ikan asin dan hasil tangkapan yang berukuran relatif kecil diolah untuk campuran makanan ternak (itik). Hasil tangkapan sampingan yang dibuang (discard catch) yaitu : buntal, ular air, anak kepiting laut dan ubur-ubur.

Permasalahan utama pada perikanan jaring tuguk adalah rendahnya selektivitas alat tangkap. Hasil tangkapan didominasi ukuran kecil yaitu stadia larva dan juvenil beberapa jenis ikan dan udang ekonomis penting dan jenis yang sepanjang daur hidupnya berukuran maksimum kecil missal ikan teri dan udang papai. Bila kondisi ini dibiarkan dikhawatirkan dalam jangka panjang akan berdampak buruk terhadap keseimbangan sumber daya ikan dan lingkungan.

Krisis dan sulitnya mendapat bahan bakar minyak oleh nelayan di muara sungai Barito menyebabkan perikanan tuguk lebih dipilih karena dalam operasionalnya tidak banyak menggunakan bahan bakar minyak (solar) dibanding usaha perikanan lainnya seperti jaring lampara dasar (bottom seine net). Peneltian ini bertujuan untuk mengetahui hasil tangkapan dan laju tangkap jaring tuguk yang beroperasi di muara sungai Barito.

\section{Metode Penelitian}

Penelitian ini dilaksanakan di Perairan Muara Sungai Barito Provinsi Kalimantan Selatan. Pengamatan lapangan dilakukan bulan Maret, Mei, Agustus dan Oktober serta data enumerator bulan Maret sampai Oktober 2018 


\section{Pengumpulan data}

Hasil tangkapan tuguk muara sungai Barito tidak didaratkan di tempat pendaratan ikan (TPI) resmi tetapi masingmasing didaratkan pada pedangang pengumpul (tauke) di desa terutama pada yang menyiaokan modal usaha dan biaya operasional seperti bahan bakar minyak, es dan biaya konsumsi. Aktivitas penangkapan perikanan tuguk trip harian karena lokasi penangkapan tidak jauh dari pemukiman nelayan. Lama perjalanan dari Desa nelayan ke lokasi penangkapan tuguk lebih kurang 1 jam perahu klotok.

Pengumpulan data untuk parameter laju tangkap dan komposisi biomas hasil tangkapan dilakukan dengan cara pengamatan langsung terhadap hasil tangkapan yang didaratkann pada pedangang pengumpul pada bulan Maret , Mei, Agustus dan Oktober dan data hasil tangkapan nelayan enumerator bulan Maret sampai Okktober 2018.

Data yang dikumpulkan meliputi spesifikasi perahu, dimensi alat tangkap dan hasil tangkapan. Data spesifikasi perahu dan dimensi alat tangkap diperoleh dengan melakukan pengukuran terhadap bagian dari alat tangkap dan perahu yang diambil contohnya.

Hasil tangkapan pada umumnya sudah dipisahkan nelayan sebelum didaratkan, berdasarkan kelompok udang dan kelompok ikan. Untuk keperluan penelitian ini seluruh hasil tangkapan diminta untuk dibawa pulang (tidak ada yang dibuang) karena biasanya hasil tangkapan (discarded catch) seperti; buntal ,ular air dan ubur-ubur langsung dibuang kelaut. Masing-masing kelompoh contoh hasil tangkapan yang didaratkan (ikan, udang dan discarded catch) dipisahkan berdasarkan jenis dan ditimbang. Identifikasi jenis dilakukan dilapangan dan laboratorium Balai Peneltian Perikanan Perairan Umum berdasarkan buku Kottelat (1993). Peristiadi,(2006), FAO (1998), Tarp T.G. and P.J Kailola (2009).

\section{Analisa data}

Analisa data dilakukan untuk memperoleh dugaan laju tangkap jaring tuguk (kg/hari) diperoleh dari :

$$
\mathrm{C}=\mathrm{B} / \mathrm{A}
$$

Dimana :

$A=$ jumlah hari operasi perahu jaring tuguk dalam setiap trip (hari)

$\mathrm{B}=$ jumlah hasil tangkapan perahu jaring tuguk pada setiap trip ( $\mathrm{kg}$ )

$\mathrm{C}=$ laju tangkap per perahu $(\mathrm{kg} / \mathrm{hari})$

Analisa data untuk memperoleh proporsi biomas :

$$
\mathrm{Pi}=\mathrm{Bi} / \mathrm{Bt} \times 100 \%
$$

Dimana :

$\mathrm{Pi} \quad=$ Proporsi biomas jenis ke $\mathrm{i}$

$\mathrm{Bi}=$ Biomas jenis ke $\mathrm{i}$

$\mathrm{Bt}=$ Biomas total

\section{HASIL DAN PEMBAHASAN \\ Deskripsi perahu dan alat tangkap}

Operasional jaring tuguk menggunakan perahu yang berukuran ,lebih kecil dari 1 gross ton, perahu jukung, ukuran panjang 7 - 9 meter, lebar 1,0 -1,2 meter dan dalam 0,9 meter. mesin tenaga pengerak inboard 12- $16 \mathrm{PK}$, proses hauling dilakukan secara manual oleh satu orang nelayan (Gambar 1).

Alat tangkap jaring tuguk merupakan alat tangkap pasif (pasang dan tunggu) banyak dioperasikan di muara sungai Barito, ditujukan untuk menangkap udang dan ikan demersal. Alat tangkap tuguk terdiri dari dua komponen utama yaitu kerangka tuguk dan jaring tuguk. Ukuran bukaan mulut jaring tuguk $6 \times 7$ meter, panjang 13 meter, meshsize 1,0 ; 0,75 dan 0,25 in sebagai kantong hasil. (Gambar 1) . 

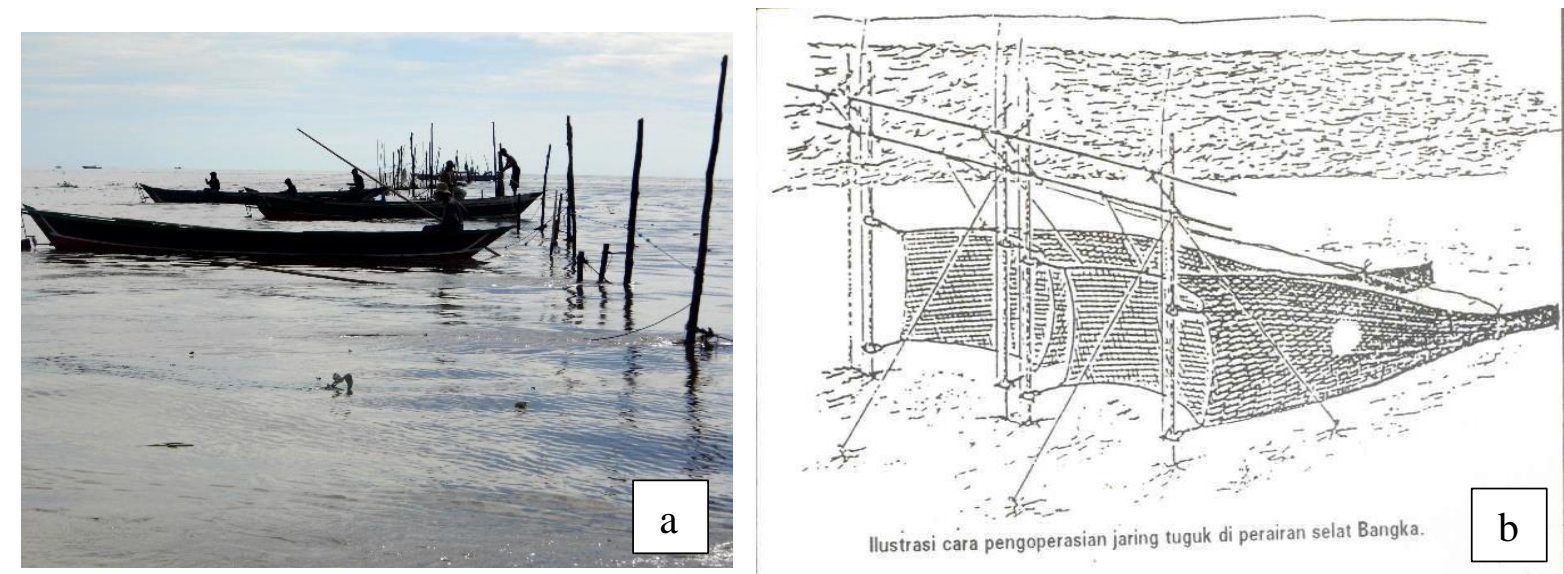

Gambar 1. (a) Perahu perikanan jaring tuguk, (b) Sketsa jaring tuguk

\section{Daerah Penangkapan}

Daerah penangkapan jaring tuguk di sekitar muara sungai Barito (Gambar 2), perairan dasar berlumpur, diluar jalur transportasi kendaraan air sesuai dengan rambu navigasi yang telah ditentukan oleh Dinas perhubungan laut. Perairan muara sungai dipengaruhi masa air tawar (freshwater discharge), tempat bertemunya masa air tawar dan air laut menyebabkan pengaruh yang kuat pada pengendapan sedimen. Sedimen yang diangkut dari aliran sungai banyak membawa unsur hara dan terperangkap di perairan muara sungai (Nutrient trapped) sehingga perairan muara sungai relatif lebih subur (Efriyeldi, 1999). Udang penaide sebagai sasaran utama lebih menyenangi perairan dangkal, berlumpur dan subur.

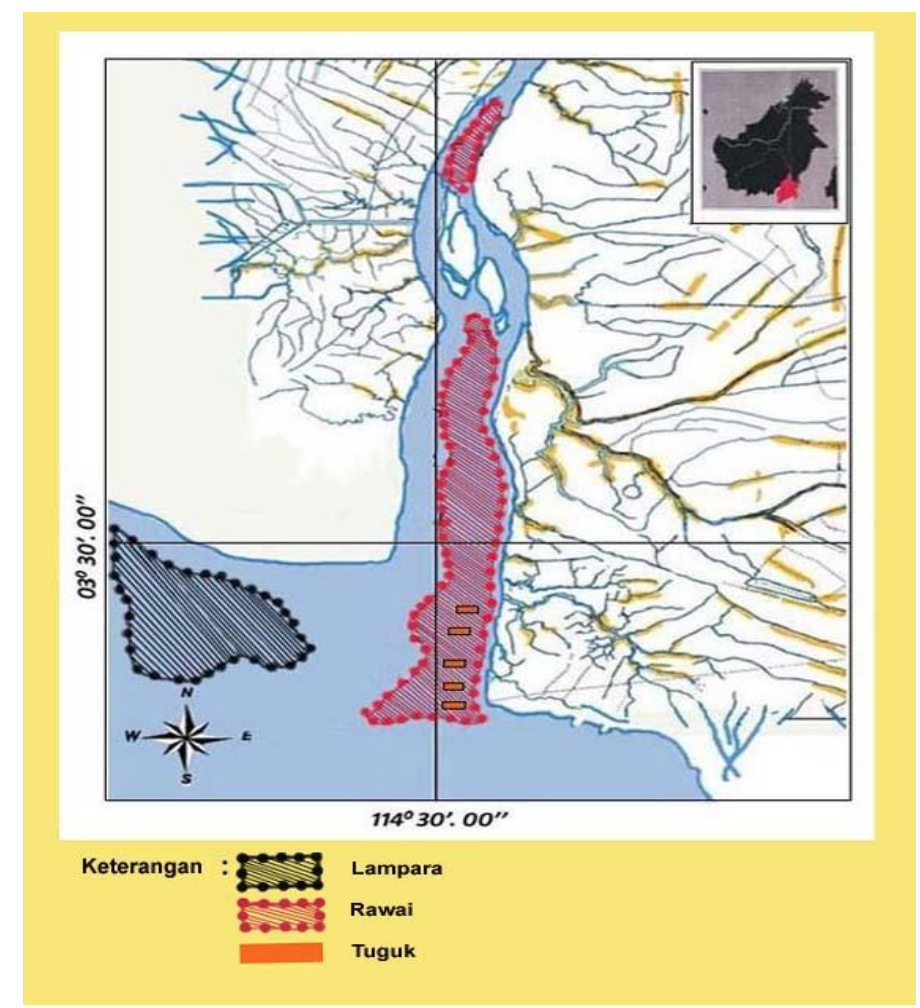

Gambar 2. Daerah penangkapan jaring tuguk 


\section{Laju tangkap}

Berdasarkan data pengamatan enumerator bulan Maret sampai Okktober lapangan dan hasil tangkapan nelayan 2018. seperti disajikan pada Tabel 1 .

Tabel 1. Rata rata laju tangkap berdasarkan bulan pengamatan .

\begin{tabular}{lc}
\hline Bulan pengamatan & Hasil tangkapan $(\mathbf{k g})$ \\
\hline Maret & 26,4 \\
April & 28,5 \\
Mei & 35,3 \\
Juni & 48,6 \\
Juli & 39,8 \\
Agustus & 37,4 \\
September & 46,2 \\
Oktober & 33,5 \\
\hline Rata-rata & 36,9 \\
\hline
\end{tabular}

Tabel 1 menunjukan bahwa kisaran rata-rata laju tangkap jaring tuguk $26,4-$ $48,6 \mathrm{~kg}$, rata-rata $36,97 \mathrm{~kg} / \mathrm{hari}$. Berdasarkan data curah hujan bulanan (Gambar 3) terjadi peningkatan laju tangkap mulai bulan Juni, yaitu awal musim kemarau sampai bulan September 2018. (Anonim, 2014). Dapat disimpulkan bahwa laju tangkap tuguk pada musim kemarau relatif lebih besar dibanding musim hujan.

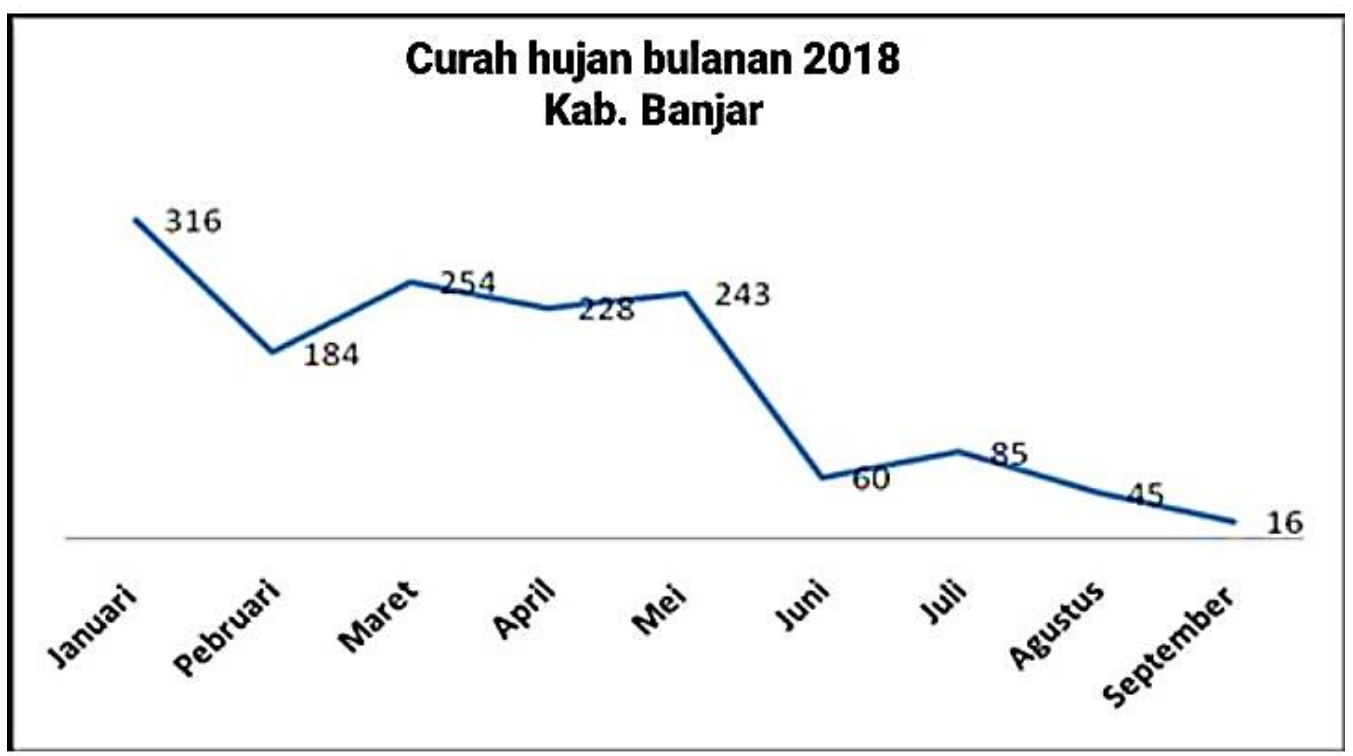

Gambar 3. Data curah hujan bulanan Kabupaten Banjar 2018

\section{Proporsi biomas hasil tangkapan}

Hasil tangkapan jaring tuguk selama peneltian diperoleh 54 jenis ikan, udang dan hasil tangkapan lainnya dari 24 famili. Hasil tangkapan udang memiliki laju tangkap lebih tinggi dibanding laju tangkap ikan. Rata-rata laju tangkap udang
23,28 kg/hari atau $63 \%$, laju tangkap ikan $12,94 \mathrm{~kg} / \mathrm{hari}$ atau $35 \%$ dan laju tangkap sampingan yang dibuang ( buntal, ular, anak kepiting laut dan teripang) $0,92 \mathrm{~kg}$ atau 2,48 \% dari total laju tangkap (Gambar 4) . 


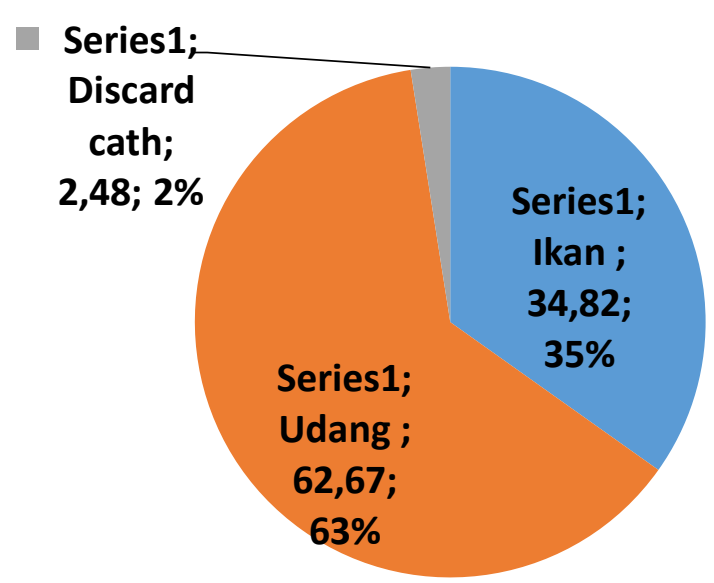

Gambar 5. Proporsi berdasarkan kelompok hasil tangkapan.

Tabel 2. Proporsi biomas hasil tangkapan jaring tuguk

\begin{tabular}{|c|c|c|c|}
\hline $\begin{array}{l}\text { No } \\
\text { (1) }\end{array}$ & $\begin{array}{l}\text { Nama local } \\
\text { (2) }\end{array}$ & $\begin{array}{l}\text { Nama ilmiah } \\
\text { (3) }\end{array}$ & $\begin{array}{c}\text { Proporsi biomas } \\
\text { (4) }\end{array}$ \\
\hline 1 & Panting & Arius oetik & 0.44 \\
\hline 2 & Panting & Arius leptonotacanthus & 0.49 \\
\hline 3 & Panting & Arius maculatus & 2.38 \\
\hline 4 & Dukang & Batrachocephalus mino & 2.70 \\
\hline 5 & Panting & Cephalocassis borneensis & 1.06 \\
\hline 6 & Panting & Osteogeneiosus militaris & 0.03 \\
\hline 7 & Selar & Caranx ignobilis & 0.03 \\
\hline 8 & Bilis & Clupeichthys bleekeri & 3.97 \\
\hline 9 & Lidah panjang & Cynoglossus lingua & 1.93 \\
\hline 10 & Pari raja & Himantura imbricata & 3.31 \\
\hline 11 & Pari cecak & Himantura uarnak & 2.33 \\
\hline 12 & Elang & Datnioides polota & 0.12 \\
\hline 13 & Tapak & Drepane punctata & 0.12 \\
\hline 14 & Bulu Ayam & Coilia lindmani & 1.20 \\
\hline 15 & Pias & Setipinna taty & 0.74 \\
\hline 16 & Belumuran & Pseudapocryptes borneensis & 0.26 \\
\hline 17 & Janjan & Trypauchenichthys typus & 0.03 \\
\hline 18 & Baga-baga & Nuchequula blochii & 0.71 \\
\hline 19 & Sotong & Sepia latimanus & 0.05 \\
\hline 20 & Sembilang & Paraplotosus albilabris & 0.78 \\
\hline 21 & Anak Menangin & Polydactylus plebejus & 0.22 \\
\hline 22 & Bulu-bulu & Polynemus dubius & 1.31 \\
\hline 23 & Kepiting Bakau & Scylla serrata & 0.29 \\
\hline 24 & Kepitinglaut & Charybdis annulata & 0.09 \\
\hline 25 & Mata galak & Ilisha elongata & 0.66 \\
\hline 26 & Kiper & Scatophagus argus & 0.35 \\
\hline 27 & Gulama & Johnius dussumieri & 2.05 \\
\hline 28 & Gulama pendek & Johnius trachycephalus & 2.83 \\
\hline 29 & Gulama & Johnius macropterus & 1.87 \\
\hline
\end{tabular}




\begin{tabular}{|c|c|c|c|}
\hline (1) & (2) & (3) & (4) \\
\hline \multicolumn{4}{|c|}{ Lanjutan Proporsi biomas hasil tangkapan jaring tuguk..... } \\
\hline 30 & Gulama & Johnius coitur & 0.26 \\
\hline 31 & Gumala panjang & Otolithoides pama & 0.49 \\
\hline 32 & Gulama & Panna microdon & 0.03 \\
\hline 33 & Lome & Harpadon nehereus & 0.18 \\
\hline 34 & Buntal kuning & Chonerhinos naritus & 0.08 \\
\hline 35 & Buntal hijau & Tetraodon fluviatilis & 0.86 \\
\hline 36 & Buntal tutul & Tetraodon nigroviridis & 0.21 \\
\hline 37 & Timah & Trichiurus lepturus & 1.20 \\
\hline 38 & Teripang kuning & Holothuria vacabunda & 0.95 \\
\hline 39 & Layur & Trichulus savala & 0.63 \\
\hline 40 & Sotong & Sepia latimanus & 0.05 \\
\hline 41 & Petek & Nuchequula gerreoidwes & 0.03 \\
\hline 42 & Udang Lining & Macrobrachium mirabile & 0.08 \\
\hline 43 & Udang Selatan & Macrobrachium equidens & 0.41 \\
\hline 44 & Udang sapit & Macrobrachium equides & 0.20 \\
\hline 45 & Udang taji & Leptocarpus potamiscus & 0.25 \\
\hline 46 & Udang Geragai & Metapenaeopsis barbata & 4.86 \\
\hline 47 & Udang kuning & Metapenaeus brevicornis & 5.19 \\
\hline 48 & Udang Bajang & Metapenaeus lysianassa & 25.90 \\
\hline 49 & Udang kaleng & Parapenaeopsis sculptilis & 8.29 \\
\hline 50 & Udang manis & Metapenaeus ensis & 2.15 \\
\hline 51 & udang putih & Metapenaeus ensis & 6.43 \\
\hline 52 & Udang papai & Acetes indicus & 8.37 \\
\hline 53 & Udang taji & Leptocarpus potamiscus & 0.26 \\
\hline 54 & Udang petak & Cloridopsis scorpia & 0.29 \\
\hline \multicolumn{3}{|c|}{ Jumlah } & 100.00 \\
\hline
\end{tabular}

Tabel 2. Menunjukan bahwa proporsi biomas hasil tangkapan kelompok udang didominasi udang bajang (Metapenaeus lysianassa) 25,9 \%, kelompok ikan didominasi ikan gulama (family Sciaenidae) $7,53 \%$ dan ikan panting (famili Ariidae) 7,10\% .

\section{KESIMPULAN}

Kegiatan menggunakan alat tangkap tuguk berdemensi ukuran bukaan mulut jaring $6 \mathrm{x}$ 7 meter, panjang 13 meter, meshsize 1,0 ; 0,75 dan 0,25 in kantong hasil. Hasil penelitian menunjukan bahwa kisaran laju tangkap tuguk $26,4-48,6 \mathrm{~kg} /$ hari, rata-rata $36,97 \mathrm{~kg} / \mathrm{hari}$. Hasil tangkapan udang memiliki laju tangkap lebih tinggi dibanding laju tangkap ikan. Rata-rata laju tangkap udang 23,28 kg/hari atau $63 \%$, laju tangkap ikan 12,94 kg/hari atau $35 \%$ dan laju tangkap sampingan yang dibuang ( buntal, ular, anak kepiting laut , ubur -ubur dan teripang) $0,92 \mathrm{~kg}$ atau $2,48 \%$ dari total laju tangkap. Proporsi biomas hasil tangkapan kelompok udang didominasi udang bajang (Metapenaeus lysianassa) $25,9 \%$, kelompok ikan didominasi ikan gulama (family Sciaenidae) $7,53 \%$ dan ikan panting (famili Ariidae) 7,10\%.

\section{UCAPAN TERIMA KASIH :}

1. Rupawan, S.E selaku penanggung jawab penelitian dan membimbing 
sehingga tersedia data yang layak guna terselesaikannya karya Tulis Ilmiah ini dapat dipublikasihakan.

2. Ir. Siti Nurul Aida, MP yang telah membimbing sehingga karya ilmia ini dapat dipublikasikan

DAFTAR PUSTAKA

Anonim. 2014. Curah hujan bulanan Kabupaten Banjar. Badan Meteorologi Klimatologi dan Geofisika Stasiun Klimatologi Banjarbaru (2014).

Anonimuos, 1998. Indentification Guide for Fishery Purposes. FAO. 1998.

Efriyeldi (1999). Sebaran spasial karakteristik sedimen dan kualitas air muara sungai Bantan tengah Bengkalis, kaitannya dengan budidaya KJA. urnal Natur Indonesia II (1) 1999.

Kottelat, M; A.J Whitten; S.N Kartikasari dan S. Wirjoatmodjo, 1993. Freshwater Fishes of Western Indonesia and Sulawesi (Ikan air tawar Indonesia bagian Barat dan Sulawesi). Periplus Edition-Proyek EMDI. Jakarta.

Peristiwady. T, 2006. Ikan-ikan laut ekonomis penting di Indonesia. Petunjuk Identifikasi. LIPI Press. 2006.

Rupawan dan Dharyati. E. 2009. Upaya, laju tangkap dan analisis usaha penangkapan udang pepeh (Metapenaues ensis) dengan tuguk baris (filtering divice) di perairan Sungai Banyuasin, Sumatera Selatan. Bawal Widya Riset
Perikanan Tangkap Vol.2 no.5 tahun 2009.

Rupawan. 2013. Pemanfaatan Sumber daya Ikan di perairan muara sungai Barito Kalimantan Selatan. Makalah seminar hasil penelitian. Puslitbang Perikanan dan Konservasi Sumber daya ikan. Jakarta 20134.

Supriharyono, 2007. Pengelolaan sumberdaya perikanan yang berkesinambungan dan ramah lingkungan. Prosiding Seminar Nasional Perikanan . Program Pasca Sarjana Universitas Sriwijaya. Palembang Desember .2007

Suyasa.N.I, M.Nurhudah, S.Rahardjo. 2010. Ekologi Perairan. Sekolah Tinggi Perikanan Jakarta. Penerbit STP Press. Jakarta.

Tarp.T.G. and P.J.Kailola. 2009. Trawled Fishes of Southtern Indonesia and Northwestern Australia. The Directorate Gen. 